\title{
RISS Stage II Plasma Cell Myeloma
}

National Cancer Institute

\section{Source}

National Cancer Institute. RISS Stage II Plasma Cell Myeloma. NCI Thesaurus. Code C141395.

Not stage I or III. (from AJCC 8th Ed.) 